\title{
$\mathrm{X}$ 線による残留応力分布測定法についで*
}

$$
\text { 平 修 二** 吉 岡 靖 夫*** }
$$

\section{On the X-Ray Method of Measurement of Residual Stress Distribution}

\author{
by \\ Shuji TAIRA \\ and \\ Yasuo YoshiokA
}

(Faculty of Engineering, Kyoto University, Kyoto) (Musashi Institute of Technology, Tokyo) is

Stress measurement by X-ray. diffraction has certainly definite advantages. It is the only nondestructive method of determining the residual stress in metallic materials. Another feature is the fact that the localized stress can be measured by this method.

In the field of mechanical and structure engineerings, it is said that residual stress in products is the problem of importance in the process of production and also in performance. The distribution of residual stress in these materials is in many cases determined by employing the destructive method, although this method has a little reliability in view of experimental procedure and has adaptability to very limited sort of materials.

Recently the experimental technique of X-ray stress measurement has been surprisingly improved in our country and the field of its application is very much enlarged.

In this connection, in the present paper, some methods of determination of residual stress by means of X-ray diffraction are demonstrated, by taking examples of specimen in the shape of plate and cylindrical bar. The equations for the calculation of residual stress are as follows:

(1) plate (the case of symmetrical residual stress distribution)

$$
\sigma=\sigma_{X}-\frac{2}{h-2 a} \int_{0}^{a} \sigma d a
$$

where $\sigma$ : residual stress at a distance $a$ from surface. $\sigma_{X}$ : measured residual stress by X-ray at the layer $a . h:$ thickness of plate.

(2) plate (the case of unsymmetrical residual stress distribution)

$$
\sigma=\sigma_{X}-\frac{2}{h-a} \int_{0}^{a} \sigma d a-\left(\sigma_{b s}-\sigma_{t a}\right)
$$

where $\sigma$ : residual stress at a distance $a$ from the top surface.

$\sigma_{X}$ : measured residual stress by X-ray method at the layer $a$.

$\sigma_{b s}$ : initial residual stress at the bottom surface.

$\sigma_{b a}$ : residual stress at the bottom surface after removing the depth $a$.

(3) cylindrical bar

$$
\begin{aligned}
& \sigma_{z}=\sigma_{z X}-\frac{2}{r^{2}} \int_{r}^{a} \sigma_{z} \cdot r \cdot d r \\
& \sigma_{t}=\sigma_{t X}-\frac{1}{r} \int_{r}^{a} \sigma_{t} \cdot d r \\
& \sigma_{r}=-\frac{1}{r} \int_{r}^{a} \sigma_{t} \cdot d r
\end{aligned}
$$

where $\sigma_{z}, \sigma_{\ell}, \sigma_{r}$ : axial, tangential and radial direction residual stress at the radius $r$.

$\sigma_{z X}, \sigma_{\ell X}$ : axial and tangential direction residual stress by X-ray method at the radius $r$ after removing from surface $a$ to $r$.

It has been found from the result of present study that among the past investigations on the measurement of residual stress by means of X-ray are many problems open to questions about interpretation of the obtained results.

\footnotetext{
* 原稿受付昭和37年 8 月 1 日，当協会第 1 回X線応力澌定シン

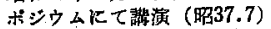

** 正員 京都大学工学部

**** 正貝 武藏工業大学
}

昭和37年11月
(Received Aug. 1, 1962)

1. 緒

X線による応力測定は, 試料表面の残留応力を非破 壊的に測定できる唯一の手段として採用されている方 
法である、そうして近時，X線発生装置：ミクロフォ トメータ，およびガイガー計数管等の発達によって， 従来之かく不傍の念を抱かれていた測定値の精度も， 著者の一人およゔ有間によりたびたび報告されている ように，充分信頼に足る精度を有するようになった，

一方，部材の残留応力の挙動を知る場合，表面の応 カのみならず，内部の残留応力分布を知りたい場合が 多々ある. 残留応力分布測定に関しては，従来より種 々の方法がとられているが，その代表的なものとして 表面より薄層を除去してい己，残留応力解放によるひ ずみ变化上り応力分布を求める除去法がある。しかし ながらこの方法は，薄層除去の際のひずみと除去厚さ との間の曲線について，曲線のこう配を図式的に求め， これより残留応力を決定するため，こう配の求め方に 対して，測定者の主観がはいり，特に表面近傍の残留 応力については，大きな誤差を生ずる可能性が大で， 極端な場合には，引張りか正縮かの判断むつきかるる 場合も起こり，得られた測定值の信頼度はきわめて低 いものと考える．この欠点は，特に応力の変化の激し いものでは致命的である.

更に，円筒の残留応力分布測定に関しては，上述の 欠点に加えて，一般に行なわれている Sachs 法では， 中心部に穿孔および中ぐりを行ない，その際のひずみ 变化上り残留応力を求めるために，高硬度の試料では 穿孔や中ぐりの加工が不可能であり，をた穿孔時の発 熱や塑性变形などによる残留応力の変化も考えられ， 適用範囲も著しく制約される。

$\mathrm{X}$ 線応力測定法は，表面残留応力を非破罗的に測定 できるという利点より，破壊的測定法である残留応力 分布の測定には，あまり使用されていないようである が，この方法に上れば，従来の除去法のようにこう 配を図式的に求めるという人為的誤差のはいる因子を 含まないので，得られるX楾測定値の精度さえよけれ ば簡単な補正をするのみで，残留応力分布が得られ， また，円筒試料でも穿孔を行なわずに，外部より薬品 による腐食除去ができるので，高硬度の試料にも適用 できるので，この分野にX線法を拡張することはきわ めて意義があるものと考える.

本報告においては，平板および中実円筒のX線によ る残留応力分布測定法について述へるとともに，その 実験例について報告するものである．

\section{X 線による残留応力分布測定法の概略}

表面よりある深さの層における残留応力を測定する には，X線によって測定できる応力は表面のものであ るために，必す測定せんとする層を露出して測定する 必要がある．この測定層露出の方法には，表層を部分 的に除去する方法と，全面的に除去する法の二とおり が考えられる。
部分的に除去する方法は，局所的な残留応力分布を 求めるに適した方法で，Fig. 1 のように表面から内部 にかけて小穴をあけて穴の底の応力を測定する方法て ある。この方法によれば，除去による応力解放はほと んどなく，得られた測定值がそのままその深さにおけ る残留応力と考えられ，表面近傍に限ればほとんど非 破壊的な方法と考えられる。

一方，全面的に除去する方法は，試料全面より徐々 に表層を除去して，新表面の残留応力を測定する方法 でこの方法によればX線法によってて測定不可能な円 筒の半径方向残留応力も，接線方向残留応力を測定す ることにより求めることが可能である。

しかしながら，表層を除去することにより残留応力 の解放が起こるので，測定値に対して補正を行なう必 要がある。

本報告では，この全面除去の方法によって残留応力 分布を求める方法について述へる。

\section{3. 板材の残留応力分布測定}

\section{（I）残留応力分布が板の中心面に対して対称と考} えられる場合

Fig. 2 のように，残留応力が板の中心に対して対称 分布をする厚さ $h$ なる板を考える。この上うな例は， 焼入烍もどしによる残留応力や压延の際に発生する残 留応力な゙があげられる。

このとき，表面から深さ $a$ の層の残留応力 $\sigma は$ 次の ように求める。

板の両側から，各 $a$ なる厚さだけ表層を除去する。 除去して現われた面の残留応力をX線によって測定し てこれを $\sigma_{X}$ とする。

両面より表層を $a$ だけ除去したために，その部分に 存在した残留応力が消失する。そうして，この応が 残部に一様に加算される，その応力を Fig. $2(\mathrm{~b})$ の ように $\sigma_{a}$ とすると

$$
\sigma_{a}=\frac{2}{h-2 a} \int_{0}^{a} \sigma d a
$$

で与えられる。

したがって， $\sigma_{X}$ は除去前の残留応力 $\sigma$ と加算され

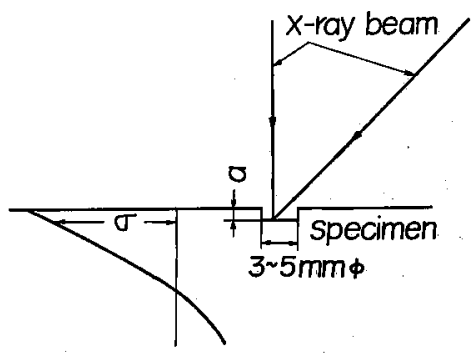

Fig. 1 The $\mathrm{X}$-ray method of residual stress distribution measurement by boring 
る応力 $\sigma_{a}$ の和と考えられる。

すなわち

$$
\sigma_{X}=\sigma+\sigma_{a}
$$

したがって，

$$
\sigma=\sigma_{X}-\frac{2}{h-2 a} \int_{0}^{a} \sigma d a
$$

右辺第二項は次の上うに求める. 除去前の表面の残 留応力を $\sigma_{s}$ とする. 第 1 回目に除去する層を $h$ に対 して充分小さくとれば, 新表面に現われる残留応力 $\sigma_{x}$ との間に近似的に次の関係が成立する。

$$
\int_{0}^{a} \sigma d a \fallingdotseq \frac{1}{2}\left(\sigma_{s}+\sigma_{X}\right) a
$$

(3)式によって第 1 回目の除去により深さ $a$ の部分 の応力 $\sigma か ゙$ 求まる. 以下順次この方法を繰り返すこと により残留応力分布を求めることが可能である.

(II) 残留応力分布が板の再面で非対称と考えられ

\section{了場合}

このような例は，板の片側に高周波焼入れを施した $\eta$ ，浸炭，各種切削研摩等の加工を与えた場合が考え られる.

この場合には，測定せんとする側より表層を除去す る，Fig. 3 に示すように，表面圧縮，内部引張りの残 留応力分布を有する板を例にして説明する。

まずFig. 3 (a) に示すように，表層を $a$ まで除去 する，その際の新表面の残留応力を $\sigma_{X}$ とする， $a$ ま で除去したために表面から $a$ 部をでに存在した残留応 力が解放されて，それが残部に加算されて，压縮側に 一様に $\sigma_{a}$ だけ增加する (Fig. $3(\mathrm{~b})$ )，同時に除去の ために板の曲率が変化して除去して現われる表面の応

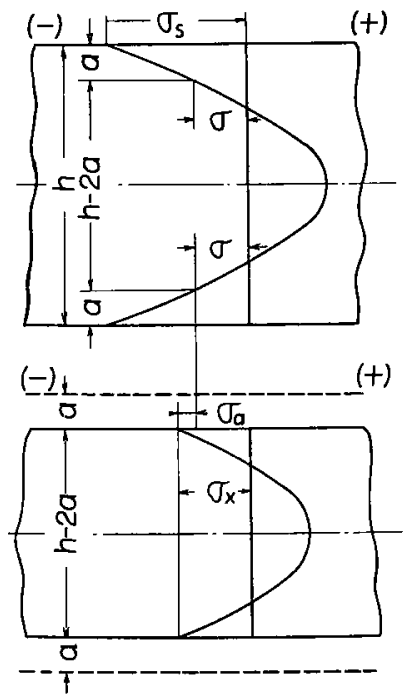

(a)

(b)

Fig. 2 Residual stress distribution of plate

(a) Initial condition

(b) After removing surface layers
力は $\sigma_{b}$ だけ王縮側に增加する (Fig. $3(\mathrm{c})$ ).

したがって，X線により測定される応力 $\sigma_{X}$ 岋次の ようになる。

$$
\text { したがって, } \begin{aligned}
& \sigma_{X}=\sigma+\sigma_{a}+\sigma_{b} \\
& \sigma=\sigma_{X}-\sigma_{a}-\sigma_{b}
\end{aligned}
$$

$\sigma_{a}$ は $3(1)$ の場合と同樣にして，次のように求める。

$$
\sigma_{a}=\frac{1}{h-a} \int_{0}^{a} \sigma d a
$$

$\sigma_{b}$ は次の方法にて求める. 測定する面の襄側の面の 残留応を表層除去のたびに測定して，その初期檤を $\sigma_{b s}$ とする，aだけ表面を除去した際にその残留応力 が $\sigma_{b a}$ になると次式が成立する。

$$
\sigma_{b a}=\sigma_{b s}+\sigma_{a}-\sigma_{b}
$$

(3)(4)式を(2)式一代入して

$$
\begin{aligned}
& \sigma=\sigma_{X}-2 \sigma_{a}+\left(\sigma_{b a}-\sigma_{b s}\right) \\
= & \sigma_{X}-\frac{2}{h-a} \int_{0}^{a} \sigma d a-\left(\sigma_{b s}-\sigma_{b a}\right)
\end{aligned}
$$

となり，深さ $a$ の部分の残留応力が求められる。

$$
\text { 4. 中実円筒の残留応力分布測定 }
$$

Fig. 4 のように, 半径 $a$ の中実円筒の半径 $r$ の層の

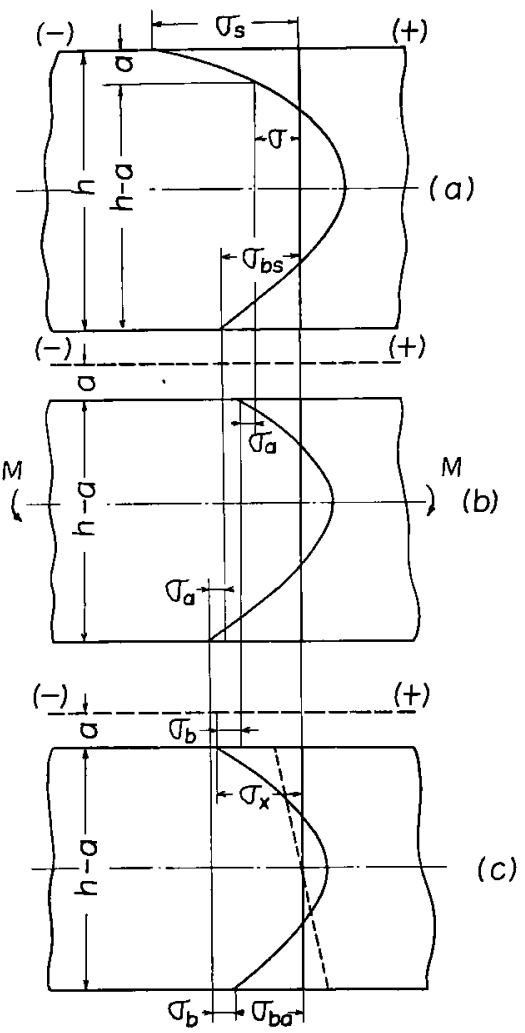

Fig. 3 Residual stress distribution of plate

(a) Initial condition

(b) (c) After removing surface layer 
三軸残留応力を求める．軸方向，接楾方向および半径 方向の残留応力をそれぞれ $\sigma_{z}, \sigma_{t}$ および $\sigma_{r}$ とする。 また， $a$ から 向と接線方向の残留応力をそれぞれ $\sigma_{z X}, \sigma_{t X}$ とする. この応力は線によって湘定される。

$a$ から $r$ をでの表面層を除去することによって，牫 留応力の解放が起こり，rの部分の応力は次のように なる。

$$
\begin{aligned}
& \sigma_{z}+\sigma_{z}{ }^{\prime}=\sigma_{z X} \\
& \sigma_{t}+\sigma_{t}{ }^{\prime}=\sigma_{t X} \\
& \sigma_{r}+\sigma_{r}{ }^{\prime}=0
\end{aligned}
$$

軸方向残留応力 $\sigma_{z}$ に関しては， $a$ から $r$ をでの部 分に存在している残留応力が表層除去により，残部に 一様に加算されたものとすると次式が成立する。 ゆえに

$$
\pi r^{2} \cdot \sigma_{z}{ }^{\prime}=\int_{r}^{a} \sigma_{z} \cdot 2 \pi r \cdot d r
$$

$$
\sigma_{z}=\sigma_{z X}-\sigma_{z}^{\prime}=\sigma_{z X}-\frac{2}{r^{2}} \int_{r}^{a} \sigma_{z} \cdot r \cdot d r
$$

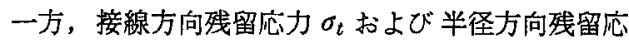
力 $\sigma_{r}$ に関しては，まず半径 $r$ の部分において次の関 係が成立する。

$$
\frac{d \sigma_{r}}{d r}+\frac{\sigma_{r}-\sigma_{t}}{r}=0
$$

この(4)式を変形すれば次のようになる。

$$
d\left(r \cdot \sigma_{r}\right)=\sigma_{t} \cdot d r
$$

(5)式を $a$ から $r$ まて積分して，さらに $r=a に$ $\sigma_{r}=0$ なる境界条件を代入すれば次のようになる。

したがって

$$
-r \cdot \sigma_{r}=\int_{r}^{a} \sigma_{t} \cdot d r
$$

$$
\sigma_{r}=-\frac{1}{r} \int_{r}^{a} \sigma_{t} \cdot d r
$$

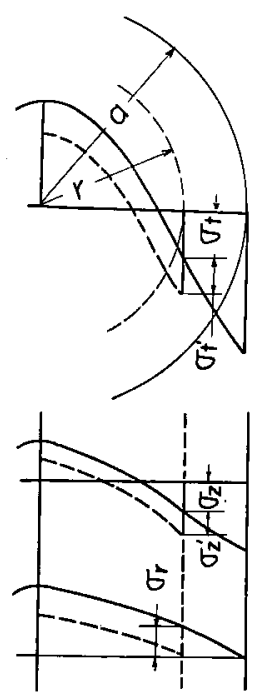

Fig. $4 i$ Residual stress distribution of cylindrical bar
また，表層を $a$ から $r$ まで除去した際に， $\sigma_{r}$ と $r$ の間のこう配が变化しないものと仮定すれば，次式が 成立する。

$$
\frac{d \sigma_{r}}{d r}-\frac{\left(\sigma_{t}+\sigma_{t}^{\prime}\right)}{r}=0
$$

したがって（4)，(8)両式より次の関係が求められ る.

$$
\sigma_{r}=-\sigma_{t}^{\prime}
$$

よって，原は次式にて求められる。

$$
\begin{aligned}
\sigma_{t} & =\sigma_{t X}-\sigma_{t}^{\prime} \\
& =\sigma_{t X}-\frac{1}{r} \int_{r}^{a} \sigma_{t} \cdot d r
\end{aligned}
$$

となり，円筒の三軸残留応力が求まる、

\section{5. 実 験 例}

上の測定法による代表的な測定例を次に述へる。

\section{(I) 使用材料}

板の場合は S55C 材で，刘称分布の例では，研削仕 上げ後， $600^{\circ} \mathrm{C}$ より水焼入れしたもの，非対称分布の 場合では， $870^{\circ} \mathrm{C}$ にて真空锛なまししたものの片面に バフ研摩を施したもので，寸法は両者とも $5 \cdot 7 \times 35 \times$ 80 のものを使用した。

中実円筒の場合は，0.2\%炭素鋼で直径 20 , 長さ 80 の丸棒を $600^{\circ} \mathrm{C} よ り$ 水焼入れをしたものである.

\section{(II) 測定装置}

測定に使用したX線装置は，ガイガー計数管を用い た自動記録式平行ビーム型ひずみ測定装置で，クロム の対隐極を用いて，(211）面の残留応力を測定した。

除去厚さの湘定はマイクロメータおよび精密てんび んによった。

表層除去は，15\%硝酸液を使用して，腐食除去中の 温度上年を防ぐために，液中にパイプにて水を通じ， 同時に摫拌を行なった。

(III) 測定結果

Fig. 5 に中実円筒の接線方向および半径方向残留応 力分布を, Fig. 6 に軸方向残留応力分布を示す．表層 においては $\sigma_{t}, \sigma_{z}$ ともに圧縮の残留庥力が生じ，中心

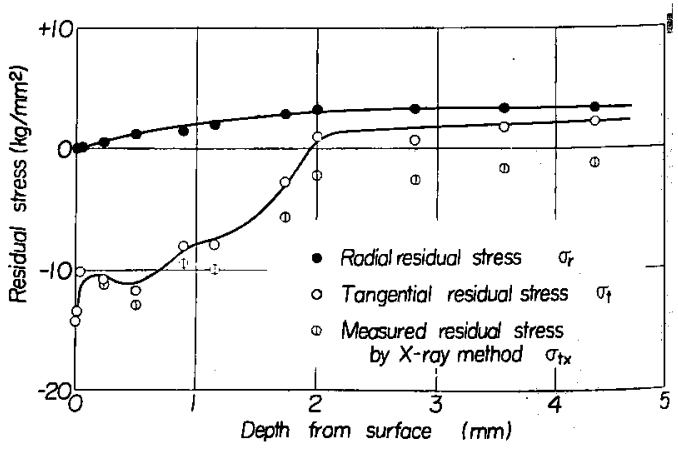

Fig. 5 Tangential and radial residual stress distribution of the cylindrical bar $\left(20 \phi \times 80,0.2 \% \mathrm{C}, 600^{\circ} \mathrm{C}\right.$ W.Q $)$ 
部で引張残留応力となる。この測定に関しては，いず れの例の場合にでも図式積分を行なう必要があり，ま た近似計算を行なう必要がある。そこで得られた X線 测定値に対して，近似計算を行なったものを第 1 近似 值として，更にこの第 1 近似值をもとにして，第 2 近 似值を求めるという逐次近似法によって，第 3 近似値 まで求めたものが Table 1 で， $\sigma_{t}$ について求めたも のである、これによれば，中心部一近くなるにつれて， 第 1 近似値と第 2 近似値の間の盖は大きくなるが，第 2 近似值の間の差はほとんどないようである。

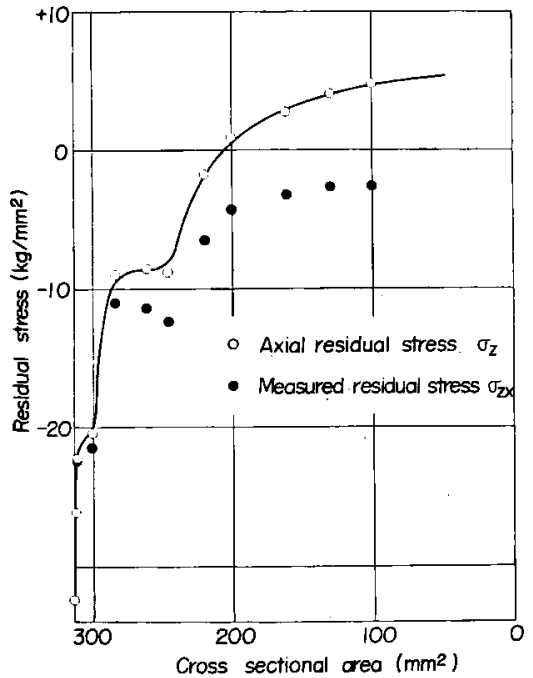

Fig. 6 Axial residual stress distribution of the cylindrical bar

$\left(20 \phi \times 80,0.2 \% \mathrm{C}, 600^{\circ} \mathrm{C} \rightarrow W . Q\right)$

Table 1 Experimental result of tangential direction residual stress at the cylindrical bar

\begin{tabular}{c|c|c|c|c}
\hline \multirow{2}{*}{ Radius } & & \multicolumn{3}{|c}{$\begin{array}{c}\text { Tangential direction residual } \\
\text { stress } \sigma_{i}\end{array}$} \\
\cline { 3 - 5 }$r$ & $\sigma_{i X}$ & $\begin{array}{c}\text { The 1st } \\
\text { order ap- } \\
\text { proximate } \\
\text { value }\end{array}$ & $\begin{array}{c}\text { The 2nd } \\
\text { order ap- } \\
\text { proximate } \\
\text { value }\end{array}$ & $\begin{array}{c}\text { The 3rd } \\
\text { order ap- } \\
\text { proximate } \\
\text { value }\end{array}$ \\
\hline 10.005 & -14.2 & -14.2 & -14.2 & -14.2 \\
9.989 & -13.4 & -13.4 & -13.4 & -13.4 \\
9.967 & -10.2 & -10.1 & -10.1 & -10.1 \\
9.778 & -11.2 & -10.7 & -10.7 & -10.7 \\
9.506 & -12.9 & -11.8 & -11.8 & -11.7 \\
9.115 & -9.5 & -7.9 & -7.9 & -8.0 \\
8.851 & -9.9 & -7.8 & -7.8 & -7.9 \\
8.365 & -5.6 & -2.5 & -2.5 & -2.7 \\
8.005 & -2.2 & +1.0 & +1.0 & +1.0 \\
7.191 & -2.6 & +1.2 & +0.7 & +0.7 \\
6.442 & -1.6 & +2.2 & +1.5 & +1.8 \\
5.670 & -1.2 & +2.7 & +2.1 & +2.2 \\
\hline
\end{tabular}

昭和37年11月

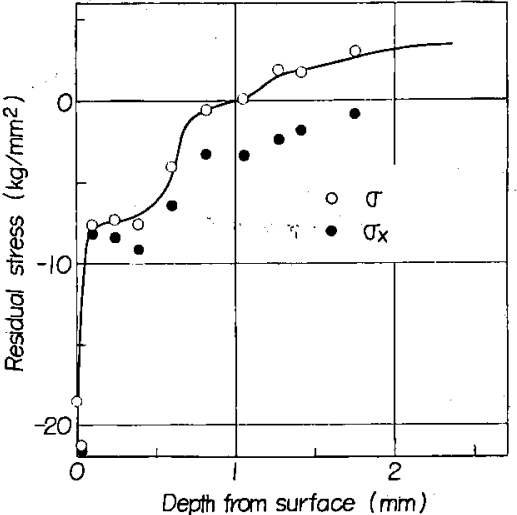

Fig. 7 Residual stress distribution of the plate $\left(5 \circ 7 \times 35 \times 80\right.$, S55C, $\left.600^{\circ} \mathrm{C} \rightarrow W . Q\right)$

Table 2 Experimental result of residual stress measurement of the plate

\begin{tabular}{c|c|c|c}
\hline $\begin{array}{c}\text { Depth from } \\
\text { surface } \\
a\end{array}$ & $\sigma_{X}$ & $\frac{2}{h-2 a} \int_{0}^{a} \sigma d a$ & $\sigma$ \\
\hline 0 & -18.5 & - & -18.5 \\
0.030 & -21.5 & -0.2 & -21.3 \\
0.099 & -8.2 & -0.6 & -7.6 \\
0.242 & -8.4 & -1.1 & -7.3 \\
0.381 & -9.1 & -1.5 & -7.6 \\
0.592 & -6.4 & -2.3 & -4.1 \\
0.812 & -3.4 & -2.8 & -0.6 \\
1.054 & -3.4 & -3.5 & +0.1 \\
1.271 & -2.4 & -4.2 & +1.8 \\
1.413 & -1.8 & -3.4 & +1.7 \\
1.752 & -0.8 & -3.8 & +3.0 \\
\hline
\end{tabular}

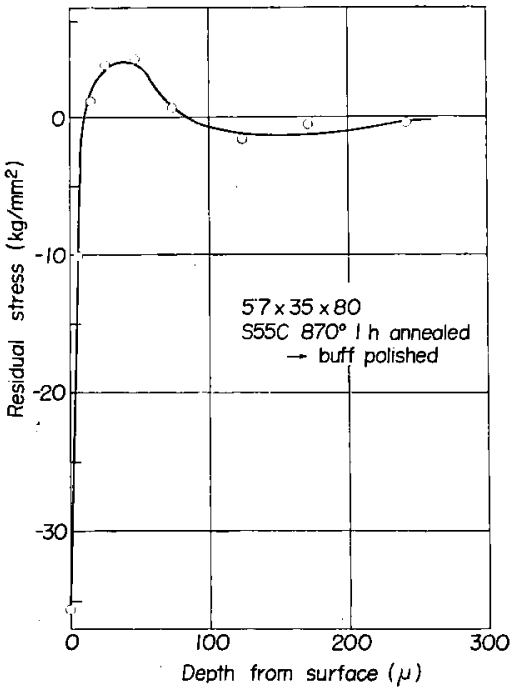

Fig. 8 Residual stress distribution of the plate (Buff polished) 
次に Fig. 7 に対称分布の場合の残留応力分布を示 す円筒の場合と同様に，表面圧樎，中心部引張りの 残留応力分布である、X線によって湘定された残留応 力はいずれも王縮応力のみであり，Table 2 に示すよ うな補正を行ない残留応力分布が求まる。

更に Fig. 8 に非対称分布をなす場合の測定例を示 す、バフ研摩を行なった場合は，表面ごく近傍にのみ 圧縮残留応力が生ずるが，直ちに减小していく，

\section{6. 実験結果の考察}

中実円筒および対称分布をなす板材では，熱応力に よる残留応力として, 表面圧縮, 内部引張りになるこ とは, 残留応力発生の機構からも明らかであり, 測定 結果もこれを表わし，残留応力の平衡条件もほは満足 しているものと考える。

また，積分項の計算も第 3 近似值を求めればほぼ充 分と考える。

したがって，X線法によって得られた応力は，著者 の一人および有間によって報告されている. 回折面依 存性の問題はあるとはいえ，機械的な残留応力に対応 するものと考えて無理はないようである。

しかしながら，この種の問題については，従来より 多くの研究が発表されているので，これらのうちの代 表的なものとの対比を試みる;

Smith と Wood によれば, 塑性引張りをした試料 の表層から順次，薄層を除去していくとき，常に圧樎 残留応力が観察されたということより，次のような解 釈を与えている。すなわち，試料内に異なった降伏応 力をもつ, A, B 二つの部分があり， $\mathrm{A}$ 部は $\mathrm{B}$ 部より 弱いものとする．外力を加えるとAはBより低い応力 で降伏してBより弾性ひずみが小さくなる，そこで除 荷すれば，B部はA部より収縮するために，引張残留 応力が生じ， $\mathrm{A}$ 部に压縮残留応力が生じて平衡を保つ. 軟鋼を引張って除荷した際に現われるX線による残留 応力は，(211)面や(310)面のものが主で,フェライト 相のものを示している。そうしてこれがセメンタイト 層の引張残留応力と平衡するために，纴縮残留応力が 湘定されるとしている，同じような結論はHauk も出 している。

しかしこれらの考察に従えば，X楾によって測定 される残留応力は，局所的に平衡しているいわゆる微 視的残留応力を測定していることになり，一般の巨視 的残留応力を測定していることにならない，ゆえに機 械的な残留応力の测定はX線法によっては不可能であ るとの結論となる。

しかしながら，Smith 5の実験では残留応力の解放 の影響を考虑に入れずに，単に薄層を除去して測定し た值をもとにした考察であり，本報告のように応力解 放の影響を考えて求めた場合には，機械的応力と対応
するものと洘えられるので，上述の考察にははなはだ 疑問の点があるものと考える.

次に，板材の非対称分布の実験例について，従来の 除去法との関連について述べる．Fig. 8 の実験例では 表面の応力は約 $-35 \mathrm{~kg} / \mathrm{mm}^{2}$ である．そうして第 1 回目の除去で表面凮を $6 \mu$ 取っている，従来の除去法 により，襄面のひずみを測定するものとして，このX 線測定值上り逆算すれば的 $-3.6 \times 10^{-6}$ となる。この ひずみは，一般の機械的ひずみ湘定法では検知不可能 であり，多くの場合，ひずみ変化はないものと考えら れる。また，抵抗線ひずみ計によっても，市販のひず み計の最小目盛が $\pm 5 \times 10^{-6}$ であることを考えれば， 精度よく測定することはほとんど不可能であり，除去 法の感度および精度は著しく低いことは明らかである。 このために Möller と Neerfeld は塑性引張りをした 円筒の表面の残留応力をX線によって測定すれば，あ る值が求まるのに対し，Sachs 法により機械的残留応 力を求めても応力は存在しないことを述へ，また， Davidenkov と Timofeeva もアルミ板について同種 の結果を出して，X線による残留応力と機械的残留応 力は異種のものであると述べているが，このような例 では残留応力はごく表層に限られるために，実験例で 示したと同様に機械的な測定法では残留応力を検知し えなかったためと考える。

\section{7. 結 論}

X線による板材および中実円筒の残留応力分布の測 定法について述へ，数種の例について実験した結果， 従来のX線応力測定に関する研究の考察の一部には， きわめて筑問とせさるるをない点が指摘され，X線応 力値が機械的残留応力に対応することを示した。

また同時に，従来より使用されている除去法につい てX楾による測定結果より検討した結果，その精度は 非常に少ないことが明らかにされた。

なお，X線による測定值も，回折面依存性があり未 解决の点はあるが，機械的測定法の精度の信頼性が小 さい現状では，X線による測定值のぼうがよりよい精 度を与えるものと考える。

\section{付 録 (X 線測定条件)}

X楾にて残留応力を湘定する際には，測定する材料 に適した回折楾および測定法を選択することが重要で ある．本実験においては，あらかじめ同種の材料につ いて予備実験を行なったところ，次の結果を得たので これをもとにして測定条件を决定した。

自動記録式では，カウント数と時定数の組合せによ って生ずる回折線像に差異が見られる，Fig. 9 は種々 の条件で求めた回折線像を示すものであり，この中で はカウント数 $200 \mathrm{c} / \mathrm{s}$, 時定数 16 秒のものがいちばん 測定しやすいものと判定して採用した．なお，時定数 


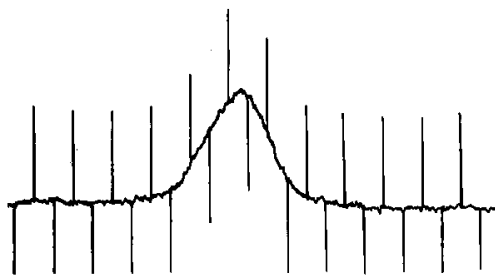

(a)

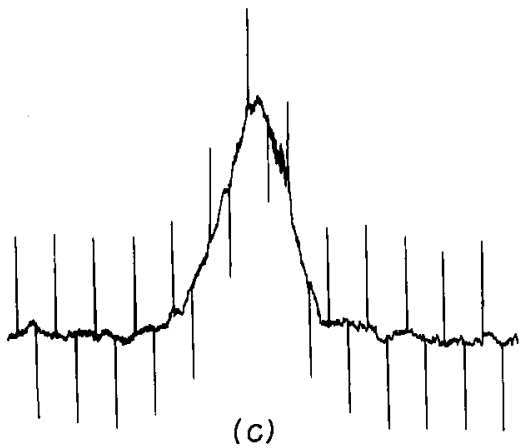

(c)
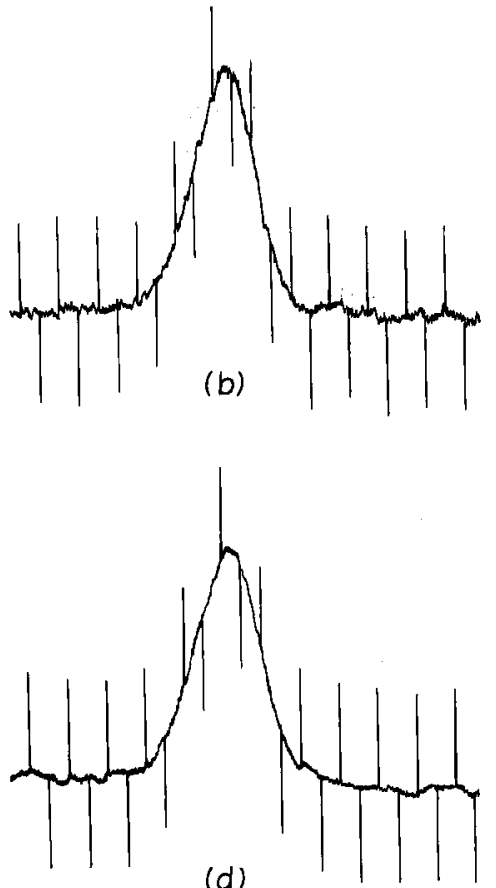

(d)

Fig. $9 \mathrm{X}$-ray diffraction pattern $\left(\mathrm{S} 55 \mathrm{C}, 600^{\circ} \mathrm{C} \rightarrow \mathrm{W} . \mathbf{Q}, \xi_{0}=45^{\circ}\right.$ )

(a) Count range (c/s) 500 , time const. (sec) 8

(b) 200 ,

(c) 100 ,

(d)

200 ,

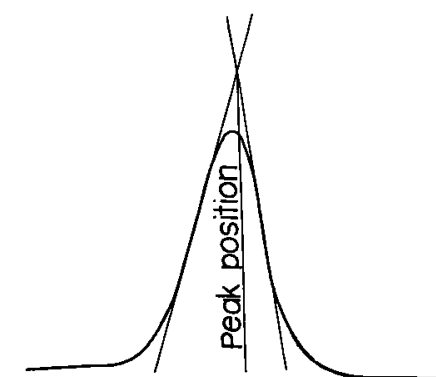

(a)

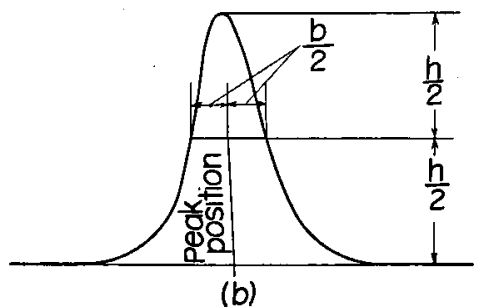

Fig. 10 Measurement methods of peak position of X-ray diffraction line

(a) Tangential method

(b) Half-value breadth method
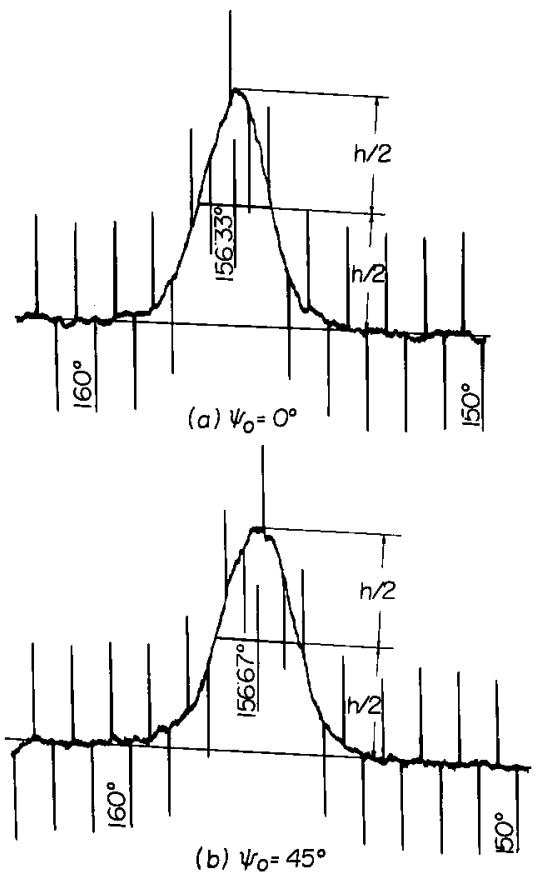

Fig. 11 An example of measurement of peak position

(S $55 \mathrm{C}, 600^{\circ} \mathrm{C} \rightarrow \mathrm{W} . \mathrm{Q}$ ) 
を長くすると，ピーク位置がずれて，格子面間隔の絶 対值測定は不適当であるが，応力測定の場合はピーク 位置の差を問題とするので，本害験では時定数を長く とり，きれいな回折線をとるようにした。

ピーク位置の測定法には Fig. 10 (a)，(b)に示す ような切線法と半価幅法とが一般に用いられている。 しかし，切線法では線の引き方によって，ピーク位置 が著しくずれる場合がある。これに対して半価幅法で はピーク高さの半分，すなわち半価幅の位置の多少の 上下によっては，ピーク位膡にほとんど影響が今回の 実験例では見られないのでここの方法を採用した。

測定例の一つを Fig. 11 に示す。

なお，厳密にいうと， $\mathrm{K} \alpha_{1}$ 線と $\mathrm{K} \alpha_{2}$ 線を分離して
ピーク位置を求める必要があるが，クロムの $\mathrm{K} \alpha_{1}$ 線と $\mathrm{K} \alpha_{2}$ 線は距離が近く，分離を行なうことが困難て実用 的ではないので，本例ではすべて $\mathrm{K} \alpha_{1}, \mathrm{~K} \alpha_{2}$ 雨回折線 の混合したものについてピーク位置を求めた。

\section{参考文 献}

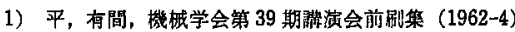

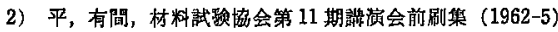

3）平，有間，X線応力测定シンボシウム前刷箱 (1962-7)

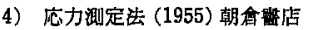

5) S.L. Smith and W.A. Wood, Proc. Roy. Soc., A. 132, 404 (1944)

6) V. Hauk, Z. Metallkde, Bd. 46, Heft. 1, 33 (1955)

7) Progress in Metal Physics, 3, (1952)

8) N.N. Davidenkov and M.N. Timofeeva, J. Tech. Phys., USSR, 16, 283 (1946)

\section{(650頁より)}

多結晶ニッケルの表面層のすべり応力と変形した材 料の残留応力に対するその影響 (The Flow Stress of Surface Layers of Polycrystalline Nickel and its Influence on the Residual Stresses in Deformed Specimens) K. Kolb and E. Macherauch, Phil. Mag., vol. 7, p. 415/426 (1962)

1949 年に Greenough は，X線を用いて材料に塑性 変形を与えた後の微小残留ひずみ(第 2 種恪子ひずみ) の大きさが結晶粒の方向により異なることを確かめ， これを多結晶の結晶粒による降伏点の相迲によって説 明し，定量的にも一致する結果を得た。しかし，その 後, Macherauch らによる研究では, アルミニウムや 銅などの f.c.c. に対してはこの Greenough の理論が あてはまらないことが結論ざれたそそこでこの論文で は、ニッケルについてこれらを調べている。

引張試験の材料は純ニッケルで，電解研摩の後，焼な ましする，断面の大きさは $2 \times 3 \mathrm{~mm}$ ，結晶粒の径は約 $30 \mu て ゙ あ る . \mathrm{X}$ 線は $\mathrm{CoK} \alpha$ 線, 標準物質としてはゲ ルマニウム粉を用い，背面反射法で $\{420\}$ と $\{313\}$ 面 を調へた，多くの結晶から反射を得るために，二つの 方法を試みた。すなわち一つは試験片を $\pm 2^{\circ}$ 振動さ せるもので，もう一つはX線管を試験片に平行に移動 させる方法である。

荷重をかけた状熊と除荷後に，それぞれ $\sin ^{2} \psi$ に対 する格子ひずみの大きさを測定したが，これらはいず
れも Greenough の理論から期待されるような曲線上 にはのらず，むしろ少しばらついてはいるが，ある傾 きの直線上にある。つまり巨視的な応力の存在を示し ている、そこでこれらから応力を求劣と，負荷状態 では表面の応力は試験片全体の平均応力上り小さい. 降伏点を過ぎると変形とともにこの差が大きくなる。 除荷後は反対方向すなわち压縮の残留応力を生じ，こ れは变形とともに增大する。

以上の結果から，まず $\sin ^{2} \psi$ に対してひずみをプロ ットすると直線からずれることがあるが：これは全く 統計的なもので, 結晶粒相互の干涉による局部的応力 によると考える。 また，Greenoughの言うように，残 留応力の発生が表面と内部の結晶との降伏応力の差に よるのならば，応力は降伏点を越すと直ちに現われ， その後一定に保たれるはずである，ところが実験結果 は残留応力がひずみとともに增大しているので，著者 らは，これを表面と内部の結晶粒との加工硬化の過程 に巨視的な不均一があることによると説明している。

$\{420\}$ 面と $\{313\}$ 面の表面残留応力は同じ傾向を示 し，ひずみとともに増大するが，定量的には $\{313\}$ の ほうが压縮応力が大さく出る。

結局, 著者らは Greenough の理論はニッケルにつ いても一般的にはあてはまらないことを結論している。

(本田和男)

(692 頁一) 